\title{
Isolated peripheral facial nerve palsy in multiple sclerosis
}

\author{
Tarig Mohammed Abkur
}

Department of Neuroscience, Imperial College Healthcare NHS Trust, London, UK

Correspondence to Dr Tarig Mohammed Abkur, tarig1982@hotmail.com

Accepted 5 November 2018
D Check for updates

(C) BMJ Publishing Group Limited 2018. No commercial re-use. See rights and permissions. Published by BMJ.

To cite: Abkur TM. BMJ Case Rep 2018;11:e228159. doi:10.1136/bcr-2018228159

\section{DESCRIPTION}

A 63-year-old man, who was on treatment with interferon beta- 1 a for relapsing remitting multiple sclerosis for the last 14 years, presented with a new isolated right-sided lower motor neuron facial palsy. He was diagnosed with a right-sided Bell's palsy, and subsequently he was commenced on oral prednisolone $60 \mathrm{mg}$ daily for 5 days, followed by a taper, and made full recovery.

MRI of the brain was performed 1 month after presentation showed a new demyelinating lesion at the right side of the pons (figure 1). Based on the MRI finding, the diagnosis was reviewed and changed to multiple sclerosis relapse, and his treatment was escalated to oral fingolimod.

Imaging of the brain in isolated peripheral facial palsy may be normal, demonstrate characteristic

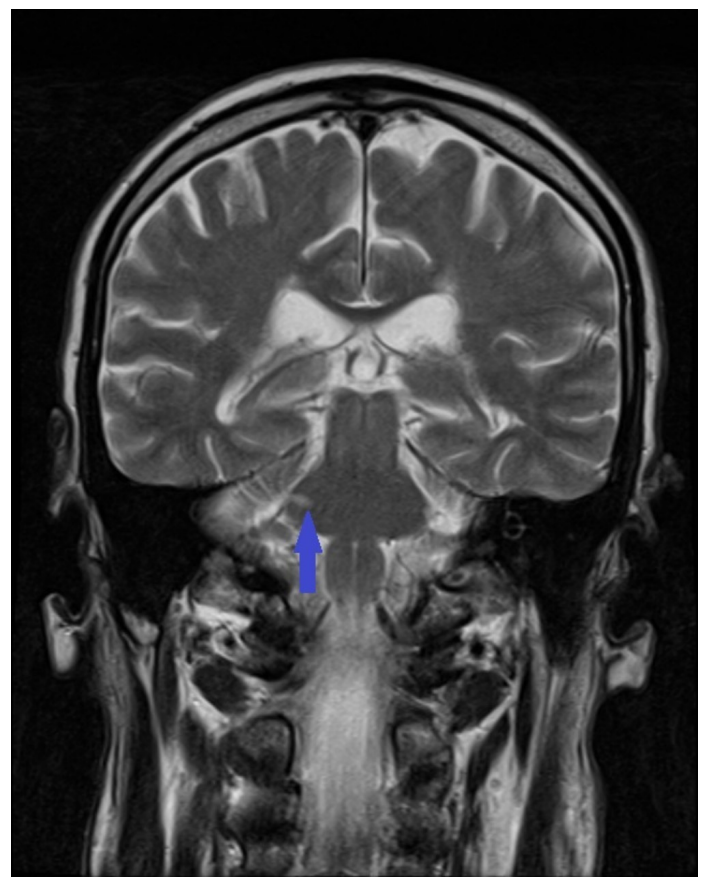

Figure 1 Coronal T2 MRI of the brain showing a new small ovoid focus of hyperintensity in the right side of the pons (arrow). labyrinthine enhancement in Bell's palsy, or abnormal signal change in the pons, for example, haemorrhage.

Multiple sclerosis is a rare cause of isolated cranial neuropathies, occurring in approximately $1.6 \%$ of all patients. The incidence of peripheral facial nerve palsy in patients with multiple sclerosis is estimated at around $0.2 \%{ }^{1}$ However, the assessment may identify features suggestive of other brainstem dysfunction such as eye movement disorder and ataxia.

Brain imaging should not be performed routinely for patients with new-onset Bell's palsy. ${ }^{2}$ However, MRI of the brain should be considered in patients who demonstrate atypical neurological manifestations outside the territory of the facial nerve.

\section{Learning points}

- Peripheral facial nerve palsy can be caused by a brain stem lesion, for example, pontine haemorrhage or demylination plaque.

- Peripheral cranial neuropathies can occur in multiple sclerosis, but usually other signs of brainstem involvement can be detected.

- Brain imaging should be considered for patients with peripheral facial nerve palsy who are found to have atypical features.

\section{Contributors TMA is the sole author.}

Funding The authors have not declared a specific grant for this research from any funding agency in the public, commercial or not-for-profit sectors.

Competing interests None declared.

Patient consent Obtained.

Provenance and peer review Not commissioned; externally peer reviewed.

\section{REFERENCES}

1 Thomke F, Lensch E, Ringel K, et al. Isolated cranial nerve palsies in multiple sclerosis. Journal of Neurology, Neurosurgery \& Psychiatry 1997:63:682-5

2 Baugh RF, Basura GJ, Ishii LE, et al. Clinical practice guideline: bell's palsy. Otolaryngol Head Neck Surg 2013;149(3 Suppl):S1-27. 
Copyright 2018 BMJ Publishing Group. All rights reserved. For permission to reuse any of this content visit https://www.bmj.com/company/products-services/rights-and-licensing/permissions/

BMJ Case Report Fellows may re-use this article for personal use and teaching without any further permission.

Become a Fellow of BMJ Case Reports today and you can:

- Submit as many cases as you like

- Enjoy fast sympathetic peer review and rapid publication of accepted articles

Access all the published articles

- Re-use any of the published material for personal use and teaching without further permission

For information on Institutional Fellowships contact consortiasales@bmjgroup.com

Visit casereports.bmj.com for more articles like this and to become a Fellow 